\title{
When the Line is Crossed... Paths to Control and Sanction Behaviour Necessitating a State Reaction
}

\author{
Marianne Wade • Marcelo Aebi • \\ Bruno Aubusson de Cavarlay • Marc Balcells • \\ Gwladys Gilliéron • Hakan Hakeri • Martin Killias • \\ Christopher Lewis • Erika Roth • Paul Smit • \\ Piotr Sobota $\cdot$ Ksenija Turkovic • Josef Zila
}

Published online: 31 July 2008

(C) Springer Science + Business Media B.V. 2008

\begin{abstract}
This article provides an overview of the various forms of proceedings available within 11 European criminal justice systems and reflects upon their core features. It also provides a picture of how far alternative, non-criminal proceedings are used by some of the systems as a different path to imposing a state reaction upon wrong-doers.
\end{abstract}

Keywords Criminal justice system content - Different forms of criminal procedure and alternatives

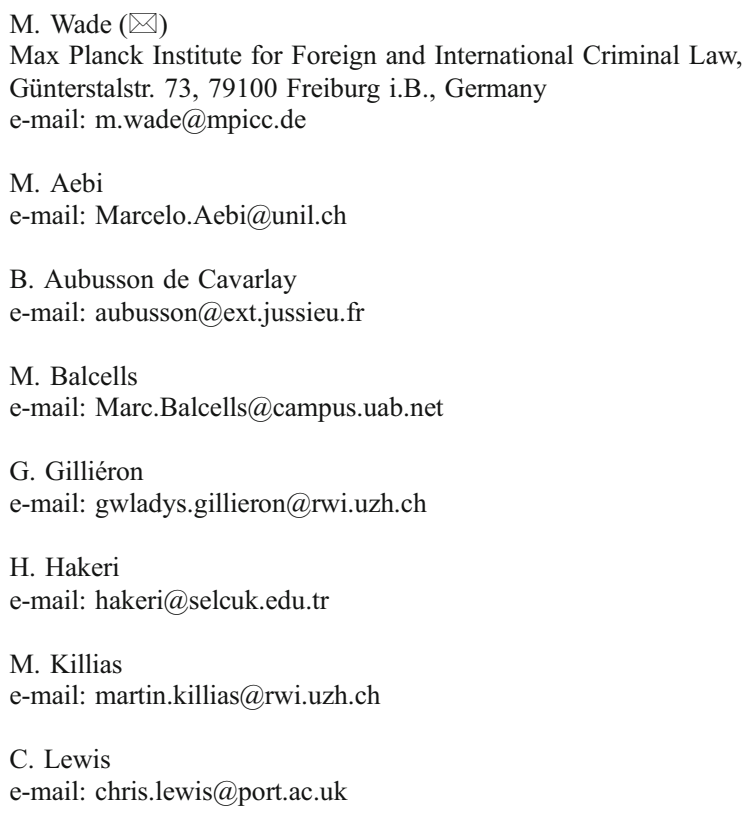


Before we can understand criminal justice systems we need to understand their purpose. First and foremost, a criminal justice system is set up to deal with forms of behaviour a state decides should be subject to a criminal sanction. However, which forms of behaviour should be included within such a system and which should not is a matter of opinion. Not surprisingly, this is reflected in the systems studied. The decision as to what is included can also change from time to time, even within a single jurisdiction. For examples of the variation between the study countries, see the case examples in Elsner et al. (2008).

Precisely what forms of behaviour are subject to criminal sanctions, and thus to the criminal justice system (CJS), varies by country. Justice systems can go outside the CJS when dealing with behaviour regarded as sanction-worthy and resort to alternative methods of dealing with such behaviour. These decisions sometimes depend on public resources that are available for the CJS, sometimes they depend on the organisations that exist within the law enforcement agencies of a particular country and their relative importance, sometimes they are a matter of history, sometimes they are a response to public outcry. Public disquiet has also led in some countries to a widening of the scope of behaviour in reaction to which the authorities are mandated to intervene; we shall see this in particular when considering England \& Wales below.

\section{Diagram 1}

Alternatives to the Criminal Justice Route ${ }^{1}$

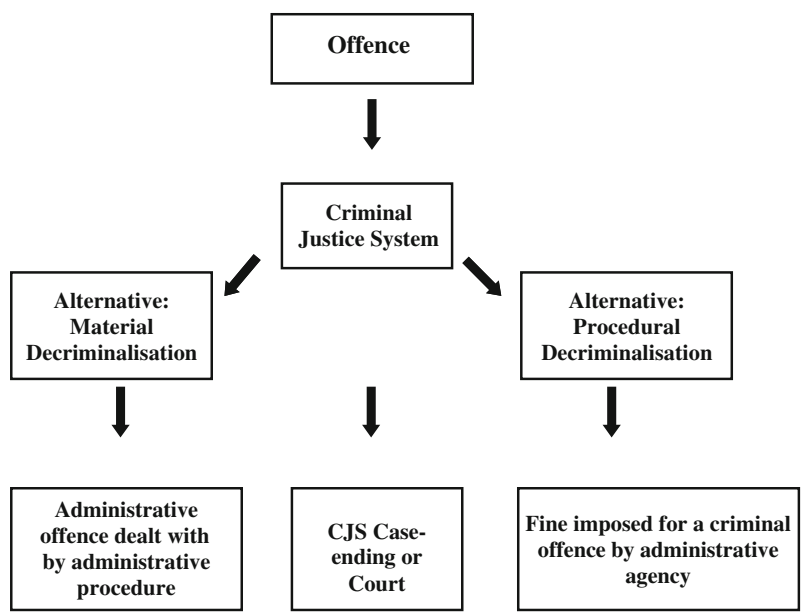

${ }^{1}$ Taken from Wade, M. 2006, p. 33

E. Roth

e-mail: jogerika@uni-miskolc.hu

P. Smit

e-mail: p.r.smit@minjus.nl

P. Sobota

e-mail: p.sobota@brpo.gov.pl

K. Turkovic

e-mail: ksenija.turkovic@zg.htnet.hr

J. Zila

e-mail: Josef.Zila@juridicum.su.se 
If any public system is considered to be overloaded, one of the easiest solutions is to decrease the volume of work entering it. In the case of criminal justice this can mean decriminalising certain behaviours or reacting to them by alternative means. The above diagram shows the theoretical options available. These are material decriminalisation, in which case an offence is removed from the CJS entirely and dealt with administratively ${ }^{2}$, there is procedural decriminalisation, which means that an offence remains formally criminal but is dealt with by non-CJS institutions and finally, there is depenalisation, meaning that an offence remains criminal and within CJS jurisdiction but is never actually punished.

The systems studied include all of the theoretical options explored, as is shown in Table 1.

Bar Turkey (where this also changed in 2005), they all feature materially decriminalised offence forms referred to as administrative offences, contraventions, offences against order or petty offences in the respective system and which are categorised as administrative offences in this study. These are formally de-criminalised and dealt with outside the CJS. ${ }^{3}$ Almost all of the systems studied have used and use this option to relieve the pressure on their system, to varying extents. This is naturally a major factor in influencing CJS statistics and must be borne in mind when considering the statistical comparisons which follow.

Some systems are also less definitive in drawing the substantive line between criminal and non-criminal offences. The status of the Polish wykrocenia or petty offences, for example, has long been the subject of academic discussion. The status of offences in England and Wales is not clearly defined. Although that system exhibits some forms of procedural decriminalisation, it has also recently witnessed a widening of the definition of behaviours because of which the state wishes to intervene, to include anti-social actions not previously the subject of any sanction at all.

\section{Offence Categories Developed by the Study}

In order to allow for comparison of the various types of offences found in the study countries, the following offence categories, developed in the pilot-study, were adopted:

Administrative offences These are offences which are dealt with outside the CJS. An action is defined as socially undesirable and worthy of a state reaction but not of one enforced by the CJS. They tend to be dealt with by standardised form, in writing. The payment of an administrative fine is the usual penalty. They may be administered by the police and, on appeal by other CJS agencies, but their nature is non-criminal. The state reaction is not considered a "true" punishment or sanction and the person accused is not given a criminal record.

Minor Offences These are the least serious offences prosecuted within the CJS. The boundary between them and administrative offences is a matter of great variation among the jurisdictions studied. They may be dealt with using different, simplified procedures compared to more serious offence categories. They are still considered to be crimes and usually — but not always - a person found guilty of them will have this fact registered and so have a criminal record as a consequence.

\footnotetext{
${ }^{2}$ For a rough estimate of how large a proportion of offences is dealt with by such means by a number of the jurisdictions studied here see: Wade, M. 2006, p. 38

${ }^{3}$ Although it should be noted that some criminal justice system institutions are often involved in these kinds of simplified "sanctioning" proceedings but in a different, non-CJS, function.
} 
Table 1 How do criminal justice systems deal with minor offences?

\begin{tabular}{llll}
\hline & by Substantive decriminalisation & by Procedural decriminalisation & by Criminal procedure \\
\hline CH & & & $X^{1}$ \\
D & $X^{2}$ & & $X^{3}$ \\
E & & $X^{5}$ & $X^{4}$ \\
EW & & $X_{\text {(mainly) }}$ & 6 \\
$F^{7}$ & $X_{\text {(rarely) }}$ & & $X$ (rarely) \\
H & $X^{8}$ & & $X^{9}$ \\
HR & $X^{10}$ & & \\
NL & & & $X^{11}$ \\
PL & $X^{12}$ & $X^{13}$ & $X^{14}$ \\
S & $X^{12}$ & $X$ & $X^{14}$ \\
TR & & $X$ & $X^{2}$ \\
\hline
\end{tabular}

${ }^{1}$ Cases that are handled by "Verzeigungsverfahren".

${ }^{2}$ Ordnungswidrigkeiten: In the 1970 some former criminal offences were decriminalized substantively and are now dealt with in an administrative procedure.

${ }^{3}$ Depends on each individual case and the perpetrator but such cases will often be dropped or disposed of by the PPS or court.

${ }^{4}$ Falta-procedure by a single judge ${ }^{1}$, mostly fine imposed (plea bargaining beforehand is very common), leads to a conviction; without any written indictment by PPS but just an oral statement at trial; appeal possible to the Tribunal.

${ }^{5}$ See examples in Table 2.

${ }^{6}$ Most types of minor offences, except summary motoring offences are dealt with this way.

${ }^{7}$ Contraventions class $1-4$ in this context (maximum penalty $=$ fine less than $560 €$ ). Contraventions of class $\mathrm{V}$ are treated in the same way as "délits".

${ }^{8}$ Some minor offences are defined as administrative offences dealt outside the CJS. E.g.: offences against property under the value-limit defined by the law or less serious traffic offences. Sometimes - following inflation — value limits are modified by legislation decriminalising some criminal offences in this way.

${ }^{9}$ If the offence is part of the Criminal Code it will be dealt with by the CJS. Discretionary power of the PPS may be used, e.g. partial omission of the indictment if a criminal offence has no significance for the purpose of liability, due to the commission of another criminal offence of greater gravity which is included in the indictment.

${ }^{10}$ In the past few years a few offences were decriminalized: a traffic accident with light bodily injury is now an administrative offence.

${ }^{11}$ Full criminal procedure. (Procedural) decriminalisation is focused on administrative offences.

12 To some extent. The admin. offences mentioned in Table 2 were previously criminal offences.

${ }^{13}$ Even if the principle of legality is valid, the PPS has many possibilities not to prosecute, especially minor offences.

${ }^{14}$ The main efforts is to avoid a full prosecution of minor offences.

Less Serious Offences an intermediate category of offences inherent in some systems, these are offences which are "real offences" in that a person found guilty of them will have a criminal record and face a "real" sanction. They may be easiest to define procedurally because they can be dealt with differently than the most serious category of offences but this is the consequence of the fact that they are felt to be less serious or alternative solutions are regarded as acceptable in response to them.

Serious Offences the most severe offences dealt with by the criminal justice system. A person found guilty of them will have a criminal record and face a "real" sanction. 
Table 2 How criminal justice systems categorize minor offences (using case examples)

\begin{tabular}{|c|c|c|}
\hline & Admin. offence & Minor criminal offence \\
\hline $\mathrm{CH}$ & $\begin{array}{l}\text { Minor traffic offences (Bundesgesetz über } \\
\text { Ordnungsbussen im Strassenverkehr) and } \\
\text { for "baselstädtische Übertretungen" } \\
\text { (Baselstädtische Ordnungsbussenliste). } \\
\text { Some can be dealt with by imposing a fixed } \\
\text { penalty (fine up to } 300 \mathrm{CHF} \text { ) }\end{array}$ & $\begin{array}{l}\text { "Übertretung": fine (over } 300 \mathrm{CHF} \text { ) or a short } \\
\text { sentence of imprisonment (1 day up to } \\
3 \text { months). }\end{array}$ \\
\hline $\mathrm{D}$ & $\begin{array}{l}\text { Ordnungswidrigkeiten: Almost all traffic } \\
\text { offences: speeding (but not excessive), traffic } \\
\text { lights, parking }\end{array}$ & $\begin{array}{l}\text { Less serious crimes Vergehen (Bagatelldelikte): less } \\
\text { serious damage to property, shop-lifting (value of } \\
\text { the stolen good }<25 \text { Euros) }\end{array}$ \\
\hline $\mathrm{E}$ & $\begin{array}{l}\text { Cannabis consumption in public places } \\
\text { (Adm. authority: imposing adm. fines) } \\
\text { speeding without alcohol and without any } \\
\text { personal danger (Police: imposing adm. fines) }\end{array}$ & $\begin{array}{l}\text { Faltas }(<400 \text { Euro damage or light injury without } \\
\text { causing medical attendance, concerning offences } \\
\text { that are laid down in the } 3 \text { rd part of the criminal } \\
\text { code), mostly sentenced to a criminal fine }{ }^{1} \text {. }\end{array}$ \\
\hline EW & & $\mathrm{All}^{2}$ \\
\hline $\mathrm{F}$ & $\begin{array}{l}\text { Administrative offences receive purely } \\
\text { administrative sanctions (e.g. tax offences). } \\
\text { But most of these offences become criminal } \\
\text { offences when the sanctions or administrative } \\
\text { decisions are refused by the offender. }\end{array}$ & $\begin{array}{l}\text { Contraventions are offences for which the penal } \\
\text { code or any other law makes provision for a } \\
\text { penal fine. Contraventions are divided into five } \\
\text { classes. Most traffic offences are minor criminal } \\
\text { offences (illegal parking is a contravention } \\
\text { class 1). Less serious bodily injury is in the same } \\
\text { category (class } 4 \text { or } 5 \text { according to the } \\
\text { consequences). }\end{array}$ \\
\hline $\mathrm{H}$ & $\begin{array}{l}\text { Administrative offence is an offence dealt } \\
\text { with administrative authorities or by the local } \\
\text { court (single judge) if the given administrative } \\
\text { offence is "punishable" by custody. Different } \\
\text { substantive and procedural rules shall be } \\
\text { applied. Examples: less serious traffic } \\
\text { offences, petty offences against property, } \\
\text { prohibited prostitution, dangerous threat. }\end{array}$ & $\begin{array}{l}\text { Minor criminal offences are dealt with by the CJS } \\
\text { (investigating authorities, PPS - or private } \\
\text { prosecutor in cases handled in the procedure on } \\
\text { private accusation - \& court). Simplified } \\
\text { procedures are available. The court without } \\
\text { involvement of a lay judge, holds a trial or a } \\
\text { public session in the "waiver of the trial" } \\
\text { procedure or may apply rules concerning the } \\
\text { omission of trial. E.g.s: bodily harm, drunk } \\
\text { driving, forgery of a document (not official), } \\
\text { rowdiness. }\end{array}$ \\
\hline HR & $\begin{array}{l}\text { Drunken driving, traffic accident with only } \\
\text { light bodily injury, family violence }\end{array}$ & $\begin{array}{l}\text { Criminal offences punishable by a fine or a } \\
\text { sentence of imprisonment }<\text { three years (e.g.: } \\
\text { bodily injury, participation in an affray, petty } \\
\text { theft, failure to render aid, coercion, threat, etc.) }\end{array}$ \\
\hline NL & $\begin{array}{l}\text { Almost all traffic offences: speeding } \\
\text { (but not excessive), traffic lights, parking }\end{array}$ & $\begin{array}{l}\text { Some more serious traffic offences: excessive } \\
\text { speeding, driving without insurance. Also } \\
\text { "travelling in public transport without a valid } \\
\text { ticket" or "being drunk and disorderly in a public } \\
\text { place" }\end{array}$ \\
\hline PL & & $\begin{array}{l}\text { Offences against order (driving above the speed } \\
\text { limit, petty theft - of goods of value no more } \\
\text { than } 250 \text { zloty/ca } 60 € \text { ) }\end{array}$ \\
\hline $\mathrm{S}$ & $\begin{array}{l}\text { Regulation is unsystematic. As admin. } \\
\text { offences are defined as behaviours punishable } \\
\text { by fines (sanction fees) which are not sanctions }\end{array}$ & $\begin{array}{l}\text { There is no formal categorization of offences } \\
\text { in Swedish law. In practice, the offences } \\
\text { with only fines as available penalties and }\end{array}$ \\
\hline
\end{tabular}


Table 2 (continued)

Admin. offence

of criminal law and are not applied by courts, but admin. bodies. E.g. sanction fees can be given for wrong data being submitted in tax procedings

TR Mainly traffic offences (driving without driving light bodily harm, misappropriation licence), begging

Minor criminal offence

offences punishable by fines or imprisonment up to six months are considered as minor offences.

${ }^{1}$ Other reactions: e.g. prohibition to drive, carry a weapon $(<1$ year), go to a certain place $(<6$ months $)$, communicate with the victim ( $<6$ months).

${ }^{2}$ No concept of administrative offences, as such. However, many types of minor motoring offences (parking, speeding, driving through lights, etc) have been subject to fixed penalty notices outside court for many years and some other offences such as minor public order offences (shoplifting, minor affrays, public drunkenness) have been so treated since 2004 .

Tables 2 and 3 show how the systems studied categorise which type of offences and how these categories have been matched to the study vocabulary. Not entirely surprisingly one sees that precisely those kinds of offences which are frequently committed, and to which a lesser social or moral stigma is associated, tend to be placed in this "punishable but not criminal" category (though it is also reasonable to assume that such categorisation will correspondingly effect the perception of such behaviour). Primarily these are traffic offences but tax offences and some special cases, e.g. in France very light forms of bodily injury, in Poland thefts of below $€ 50$ value ${ }^{4}$, are also included. One should, however, note that there can be no claim of a unitary "European" moral line. Some offences considered of minor importance in one jurisdiction are taken quite seriously in others e.g. speeding above a certain point and drunk driving in particular.

\section{The Range of Procedures and Case-ending Decisions Available in Each Jurisdiction}

As was necessary in relation to offences, the specifically developed typology of procedures and case-ending decisions (by which a procedural step after which proceedings are considered finished by the institutions involved is meant) used in the initial study were adopted. They are as follows:

Administrative Reaction refers to the kinds of proceedings described above to deal with administrative offences. These are non-CJS reactions, usually imposing the obligation to pay a financial penalty, with little evidence presented and no necessity for the accused to be heard. They are carried out in writing only.

Paper Reaction A CJS reaction, involving a judge but evidence is presented in summary form and in writing. The police or PPS send a minimal account of the offence to a court requesting a certain punishment, possibly together with the case file prepared by them. There is no formal hearing unless a party entitled to do so demands one. These are the deciding court and the suspect, who is convicted and informed of this fact in writing and at the same time receives notice of his or her right to object within a limited time-frame, thereby forcing a full trial. This form of case-ending leads to a conviction (meaning a sanction and a criminal record, the

\footnotetext{
${ }^{4}$ This was true for most of the study period, though their status was always subject to discussion. As of 2001 they are regarded by most as having been brought back into the CJS (see Table 2) but see also Poland below.
} 
Table 3 Offence categorisation according to the study scheme: national jurisdictional categories ascribed to study categories

\begin{tabular}{|c|c|c|c|c|}
\hline & Admin. offences & Minor offences & Less serious offences & Serious offences \\
\hline $\mathrm{CH}$ & Police $^{1}$ & Single Judge ${ }^{2}$ & $\begin{array}{l}\text { Single Judge }{ }^{2} / \text { Full } \\
\text { bench of three } \\
\text { judges }{ }^{3}\end{array}$ & $\begin{array}{l}\text { Full bench of three } \\
\text { judges }^{3} / \text { Chamber }^{4}\end{array}$ \\
\hline $\mathrm{D}$ & & Amtsgericht $^{5}$ & Amtsgericht $t^{5}$ & Landgericht $^{6}$ \\
\hline E & $\begin{array}{l}\text { Adm. auth. } \\
\text { or Police }\end{array}$ & Single Judge ${ }^{7}$ & $\begin{array}{l}\text { Single Judge }{ }^{8} \\
\text { Tribunal }^{9}\end{array}$ & Tribunal $^{10}$ \\
\hline EW & & $\begin{array}{l}\text { Magistrates } \\
\text { Court }^{11}\end{array}$ & Magistrates Court ${ }^{12}$ & Crown Court ${ }^{13}$ \\
\hline $\mathrm{F}$ & & $\begin{array}{l}\text { Tribunal de } \\
\text { Police }^{14}\end{array}$ & $\begin{array}{l}\text { Tribunal } \\
\text { Correctionnel }^{15}\end{array}$ & Cour d' Assises ${ }^{16}$ \\
\hline $\mathrm{H}$ & $\begin{array}{l}\text { Adm. auth. } \\
\text { and Local } \\
\text { Court (single } \\
\text { judge) }\end{array}$ & $\begin{array}{l}\text { Local Court } \\
{\text { (single judge })^{17}}^{\text {single }}\end{array}$ & $\begin{array}{l}\text { Local Court (single } \\
\text { judge) })^{18}\end{array}$ & $\begin{array}{l}\text { Local Court (panel) or } \\
\text { County Court }\end{array}$ \\
\hline HR & $\begin{array}{l}\text { Administrative } \\
\text { court (single } \\
\text { judge) } 19\end{array}$ & $\begin{array}{l}\text { Municipal court/ } \\
\text { single judge }\end{array}$ & $\begin{array}{l}\text { Municipal Court } \\
\text { (panel: } 1 \text { judge }+2 \\
\text { lay judges) }\end{array}$ & $\begin{array}{l}\text { County court (panel: } \\
1 \text { judge }+2 \text { lay judges } \\
\text { or } 2 \text { judges }+3 \text { lay } \\
\text { judges) }\end{array}$ \\
\hline NL & $\begin{array}{l}\text { Administrative } \\
\text { authority }\end{array}$ & $\begin{array}{l}\text { Lower Court - } \\
\text { (Kantonrechter: } \\
\text { Single cantonal } \\
\text { judge of a district } \\
\text { court }^{23} \text { ) }\end{array}$ & $\begin{array}{l}\text { Rechtbank (Single } \\
\text { judge, called the } \\
\text { Politierechter) }^{24}\end{array}$ & $\begin{array}{l}\text { Rechtbank(Full bench } \\
\left.\text { of three judges }{ }^{25}\right)\end{array}$ \\
\hline PL & & District Court ${ }^{26}$ & District Court ${ }^{27}$ & Regional Court \\
\hline $\mathrm{S}$ & & District Court & District Court & District Court \\
\hline $\mathrm{TR}$ & & $\begin{array}{l}\text { Minor court } \\
(\text { single judge })^{28}\end{array}$ & $\begin{array}{l}\text { Main court } \\
{\text { (single judge })^{29}}^{\text {(sing }}\end{array}$ & Chamber $^{30}$ \\
\hline
\end{tabular}

\footnotetext{
${ }^{1}$ Imposing a fixed penalty (fine $<300 \mathrm{CHF}$ ) mainly for minor traffic offences.

${ }^{2}$ Cases in which a sentence of 1 day up to 3 months of imprisonment foreseen.

${ }^{3}$ Cases in which a sentence of 3 days up to 3 years of imprisonment foreseen.

${ }^{4}$ Cases in which a sentence of 1 year up to 20 years of imprisonment foreseen.

${ }^{5}$ Cases in which a sentence of up to 4 years of imprisonment foreseen.

${ }^{6}$ Cases with legal provision for a prison-sentence of more than 4 years.

${ }^{7}$ Single judge and the EM are the same person; Cases in which a sentence of 10 days up to 2 months of
} imprisonment foreseen.

$8<5$ years of imprisonment.

${ }^{9}<9$ years of imprisonment.

$10>9$ years of imprisonment.

11 Summary offences.

12 Triable either way offences (depends on the situation and the type of offence).

${ }^{13}$ Indictable offences/ also possible for triable either way offences.

${ }^{14}$ Contraventions class $1-5$ (fine $<1,500 €$ ).

15 Delits (fine or imprisonment $<10$ years).

16 Crimes (imprisonment from 10 years to life).

17 Cases for which a sentence of up to 3 years imprisonment is foreseen. Some minor and less serious cases are referred to the competence of the county court by the Code of criminal procedure. They are punishable by a sentence of less than 3 or 8 years imprisonment but of a significant danger for society. 
${ }^{18}$ Cases for which a sentence of up to 8 years of imprisonment is foreseen.

${ }^{19}$ Administrative offences - offences punishable by a fine or imprisonment for a term of 60 days maximum. At first instance these cases are considered by an administrative judge sitting alone and in the second instance decided by a panel consisting of 3 administrative judges. (art. 93 and 94 of the Act on Administrative Offences - AAO).

${ }^{20}$ Criminal offences punishable by a fine or imprisonment for a term of less than five years as principal punishment are considered by a municipal judge sitting alone.

${ }^{21}$ Municipal courts (sitting in panels of one judge and two lay judges) have jurisdiction to adjudicate at first instance offences punishable by a fine or imprisonment for a term of less than ten years as principle punishment. There are two exceptions in relation to the composition of the municipal court:

1. Criminal offences punishable by a fine or imprisonment for a term of less than five years as principal punishment are considered by a municipal judge sitting alone, with the exception of certain limited number of offences such as negligent homicide, bodily injury etc. see art. 18/2 Criminal Procedure Act;

2. The parties may agree before the trial begins that the trial of criminal proceedings for criminal offences punishable by $<10$ years imprisonment shall be conducted by the president of the panel as a judge sitting alone, unless a special law prescribes the panel composition. He shall have the powers of a panel. The parties may not retract this consent.

${ }^{22}$ First instance county courts sit in panels of one judge and two lay judges when considering offences punishable by $>10$ years imprisonment, in panels of two judges and three lay judges when considering offences punishable by $>15$ years or long-term imprisonment.

${ }^{23}$ For all infractions and some less serious crimes.

${ }^{24}$ All offences for which a sentence of up to one year of imprisonment is foreseen.

${ }^{25}$ For all crimes, especially more serious crimes.

${ }^{26}$ Petty offences (wykroczenia), heard by Mag. Division of District Courts.

${ }^{27}$ Less serious cases heard by Mag. Division of District Courts.

${ }^{28}$ Cases for which a sentence of $<2$ years imprisonment, a fine or measure is foreseen.

${ }^{29}$ Cases not in the jurisdiction of a minor court and jury court (Schwurgericht).

${ }^{30}$ Cases for which a sentence of more than 10 years imprisonment is foreseen.

French system provides an exception with the contraventions 1-4th class) and so are concentrated criminal proceedings, which take place solely on paper in the majority of cases. They are a procedurally less strenuous reaction because they apply lesser standards to the evidence upon which the deciding institution bases its judgement; more to the point the written evidence provided by the preparing institution is valued higher than it would be in full proceedings.

Drop (evidence/factual) A pre-court CJS institution ends criminal proceedings because there is insufficient evidence to support a prosecution or because some legal ground bars it.

Drop (public interest) A pre-court CJS institution ends criminal proceedings and there is no further consequence for the suspect although he or she is presumed to be guilty of the offence (i.e. the prosecutor or police officer dealing with the cases estimates that there is enough evidence against the suspect to justify taking the case to court, e.g. because a reasonable chance of conviction exists) because in weighing all aspects of the case and surrounding circumstances, considerations overweigh which mean the case is not worth prosecuting. Such a case-ending may be subject to court approval.

Conditional disposal a pre-court CJS institution disposes of a case meaning that it does not merely halt the proceedings but attaches some kind of consequence or condition to doing so. Often it requires some activity by the suspected offender. If s/he accepts and fulfils the condition attached, this ends the case and the disposal spends the state's right to prosecute 
for the offence the person is suspected of. There is a presumption (but not a finding) of guilt, with which the offender is regarded as agreeing in fulfilling the condition. Such a case ending may be subject to court approval.

Penal order this is the classic CJS paper reaction. The pre-court CJS institution issues an application for a punishing order to be issued, it is made in writing and the court approves or refuses it. Where it is issued, affected parties have the right to appeal during a certain time period after which, if they do not do so, they are convicted of the offence and subject to the punishment stated. It is a particularly efficient CJS procedure for achieving a conviction and certain punishments for certain offences.

Accelerated Proceedings This category contains other procedural forms which involve the court in deciding whether a suspect is guilty of an offence or not but they allow certain procedural short-cuts either before the case is taken to court or in the way it is presented to court in comparison to a full-trial.

Negotiated Settlement This is a fairly new type of proceedings emerging in some of the jurisdictions studied which involves an agreement being made between the prosecution and the defence as to what offence is to be charged and/or which punishment is to ensue as the state reaction to it. This agreement must be approved by a court but after a brief hearing only. A conviction and sanction ensues. The rights of parties to appeal against the resulting judgement are strongly limited.

Full/Normal Trial the CJS path which the respective system holds as the path which should represent the norm in dealing with criminal offences. A conviction and sanction results for a suspect found guilty of an offence tried in a public trial with evidence being presented fully. It is the legally "normal" path; the classic form of proceedings for which the system was conceived.

Table 4 provides an overview of which type of proceedings, criminal justice or otherwise, are available in which of the criminal justice systems studied. Again the results found are categorised according to umbrella categories developed in the course of the first stage of this project and described above. Table 4 also displays how national proceedings are categorised accordingly. They describe a procedural step by which cases are dealt with in a way considered final by the institution dealing with them and are as follows.

The range of options available alone provide some indication of the need felt to provide alternatives to a full criminal trial, presumably in order to relieve the workload pressures faced by criminal justice systems. The function of these various proceedings was explored in the course of this study.

In Croatia $^{5}$ there is only one category of criminal offences punishable by a minimum of 30 days and maximum of 40 years of imprisonment. Since 1997 (a major reform of Criminal Code and Criminal Procedure Act was undertaken in 1997) we have witnessed material as well as procedural decriminlisation in Croatia. Certain types of offences, previously considered criminal were de-criminalized in 1997 and became offences against order dealt with by special mixed administrative-criminal proceedings. For example traffic violations and a large number of forms of behaviour viewed as socially unacceptable, fall into this category.

\footnotetext{
${ }^{5}$ K. Turković. School of Law, Chair for Criminology and Criminal Law, University of Zagreb, Trg marsala Tita 14, 1000 Zagreb, Croatia. e-mail: ksenija.turkovic@zg.htnet.hr.
} 
In 1997 and later 2003 certain new procedural forms have been introduced for criminal proceedings such as the conditional disposal, penal order and rendering a judgment upon request of the parties during investigation, which is a form of plea bargaining. These procedural forms are an effective means of procedural simplification and for reducing both the PPS and the court workload and speeding up criminal proceedings. Consensual modes

Table 4 Types of reaction available (by Law) first instance

\begin{tabular}{|c|c|c|c|c|}
\hline & $\begin{array}{l}\text { Administrative } \\
\text { offence }\end{array}$ & $\begin{array}{l}\text { Minor criminal } \\
\text { offences }\end{array}$ & $\begin{array}{l}\text { Less serious } \\
\text { criminal offences }\end{array}$ & $\begin{array}{l}\text { Serious criminal } \\
\text { offences }\end{array}$ \\
\hline $\begin{array}{l}\text { Admin. reaction } \\
\text { by purely admin. } \\
\text { authority }\end{array}$ & $\begin{array}{l}\mathrm{CH}, \mathrm{D}, \mathrm{E}, \mathrm{F}, \mathrm{NL}, \\
\mathrm{H}, \mathrm{HR}^{1}, \mathrm{PL}, \mathrm{S}, \mathrm{TR}\end{array}$ & $\mathrm{EW}, \mathrm{F}^{2}$ & & \\
\hline $\begin{array}{l}\text { Admin. reaction } \\
\text { by police }\end{array}$ & $\begin{array}{c}\mathrm{CH}, \mathrm{D}, \mathrm{E}, \mathrm{F}^{3}, \mathrm{NL} \\
\mathrm{H}, \mathrm{HR}^{4}, \mathrm{PL}, \mathrm{TR}\end{array}$ & $\mathrm{F}^{2}, \mathrm{EW}, \mathrm{PL}$ & & \\
\hline $\begin{array}{l}\text { Admin. reaction } \\
\text { by PPS }\end{array}$ & $\mathrm{H}^{5}, \mathrm{TR}, \mathrm{HR}^{6}$ & & & \\
\hline $\begin{array}{l}\text { Drop (evidential) } \\
\text { by police }\end{array}$ & & $\mathrm{CH}^{7}, \mathrm{EW}, \mathrm{PL}$ & $\mathrm{CH}^{7}, \mathrm{EW}, \mathrm{PL}^{8}$ & EW \\
\hline $\begin{array}{l}\text { Drop (p.i.) or } \\
\text { disposal by police }\end{array}$ & & $\begin{array}{l}\mathrm{CH}^{9}, \mathrm{EW}, \mathrm{NL}^{10}, \\
\mathrm{~S}\end{array}$ & $\mathrm{CH}^{11}, \mathrm{EW}, \mathrm{NL}^{12}$, & EW, \\
\hline $\begin{array}{l}\text { Drop (p.i.) or } \\
\text { disposal by PPS }\end{array}$ & $\mathrm{HR}^{13}$, & $\begin{array}{c}\mathrm{CH}, \mathrm{D}, \mathrm{EW}, \mathrm{F} \mathrm{NL} \\
\mathrm{H}, \mathrm{HR}^{14}, \mathrm{~S}, \mathrm{TR}\end{array}$ & $\begin{array}{l}\mathrm{CH}, \mathrm{D}, \mathrm{EW}, \mathrm{F}, \mathrm{NL} \\
\mathrm{H}, \mathrm{HR}^{15}, \mathrm{~S}\end{array}$ & $\mathrm{CH}, \mathrm{EW}, \mathrm{F}, \mathrm{NL}, \mathrm{H}$ \\
\hline $\begin{array}{l}\text { Drop (evidential) } \\
\text { by PPS }\end{array}$ & & $\begin{array}{l}\mathrm{CH},(\mathrm{E})^{16}, \mathrm{EW}, \mathrm{F}, \\
\mathrm{NL}\end{array}$ & $\begin{array}{l}\mathrm{CH},(\mathrm{E})^{16}, \mathrm{EW}, \mathrm{F}, \\
\mathrm{NL}\end{array}$ & $\begin{array}{l}\mathrm{CH},(\mathrm{E})^{16}, \mathrm{EW}, \mathrm{F}, \\
\mathrm{NL}, \mathrm{PL}\end{array}$ \\
\hline $\begin{array}{l}\text { Paper reaction } \\
\text { by police to court }\end{array}$ & & $\mathrm{CH}, \mathrm{EW}, \mathrm{PL}$ & $\mathrm{CH}, \mathrm{EW}^{17}$ & \\
\hline $\begin{array}{l}\text { Paper reaction by } \\
\text { police, not to court }\end{array}$ & $\mathrm{H}^{18}, \mathrm{HR}^{19}$ & $\mathrm{EW}, \mathrm{S}$ & EW & EW \\
\hline Police prosecution & $\mathrm{H}, \mathrm{CH}, \mathrm{PL}$ & $\mathrm{CH}, \mathrm{PL}$ & $\mathrm{CH}$ & \\
\hline $\begin{array}{l}\text { Prosecution by } \\
\text { other authorities }\end{array}$ & PL & $\mathrm{E}^{20}, \mathrm{EW}$ & EW & \\
\hline $\begin{array}{l}\text { Paper reaction by PPS } \\
\text { to court }\end{array}$ & & $\begin{array}{l}\mathrm{CH}, \mathrm{D}, \mathrm{F}, \mathrm{H}, \mathrm{HR}^{21}, \\
\mathrm{PL}, \mathrm{TR}\end{array}$ & $\begin{array}{l}\mathrm{CH}, \mathrm{D}, \mathrm{F}, \mathrm{PL}, \\
\mathrm{TR}\end{array}$ & $\mathrm{CH}, \mathrm{PL}, \mathrm{TR}$ \\
\hline $\begin{array}{l}\text { Paper reaction by } \\
\text { PPS not to court }\end{array}$ & $\mathrm{H}^{22}, \mathrm{HR}$ & $\mathrm{EW}, \mathrm{H}^{22}, \mathrm{~S}, \mathrm{TR}$ & $\mathrm{EW}, \mathrm{H}^{22}, \mathrm{~S}$ & $\mathrm{EW}, \mathrm{H}^{22}$ \\
\hline $\begin{array}{l}\text { Full criminal } \\
\text { trial }\end{array}$ & $\mathrm{E}, \mathrm{H}, \mathrm{HR}^{23}, \mathrm{PL}$ & $\begin{array}{l}\text { CH, D, E, EW, F, } \\
\text { NL, H, HR, PL, S, } \\
\text { TR }\end{array}$ & $\begin{array}{l}\text { CH, D, E, EW, } \\
\text { F, H, HR, NL, } \\
\text { PL, S, TR }\end{array}$ & $\begin{array}{l}\text { CH, D, E, EW, F, } \\
\text { NL,H, HR, PL, S, } \\
\text { TR }\end{array}$ \\
\hline
\end{tabular}

\footnotetext{
${ }^{1}$ Administrative order can be issued by various inspections and administrative authorities for administrative offences these authorities have discovered in the course of their regular work. It could also be issued by legal persons that have public authority within the limits of the authorities they have been given. A person may be ordered to pay a fixed penalty by administrative order, if the penalty is not fixed then this will be the minimum penalty for the particular administrative offence. In addition an administrative order may extend to a protective measure and may order confiscation and compensation if there is a "price" list for the particular damage caused. An appeal is possible. If the authority collects the fine on the spot instead of issuing an administrative order it will issue a certificate of payment to the perpetrator.

${ }^{2}$ Fixed penalty for contraventions class $1-4$.

${ }^{3}$ Fixed penalty.

${ }^{4}$ In cases in which the police may issue an administrative order, if the perpetrator opts to pay a fine on the spot instead of being issued an administrative order the police will issue a certificate of payment for the administrative offence committed. See supra note 1 for further details.
} 
${ }^{5}$ PPS acts as the supervisor of legality of administrative procedures carried out by an administrative authority.

${ }^{6}$ May issue administrative order upon a report of an administrative offence by police or other authorities. See supra note 1 and 4 .

${ }^{7}$ On evidential grounds (only for traffic offences and some other minor criminal offences).

${ }^{8}$ Subject to PPS approval.

${ }^{9}$ Only when offender is "punished" by the offence itself.

${ }^{10}$ This study categorizes Overtredingen as minor criminal offences; they are substantively regarded as criminal.

${ }^{11}$ Only when the offender is "punished" by the offence itself.

12 Transactie in case of driving under influence of alcohol (until 1/1/2004) and shoplifting.

${ }^{13}$ PPS may decide in accordance with the principle of opportunity to drop or dispose the case if an administrative offence is of a lower degree of guilt and where the scope of the damaging consequences does not require the public benefit of administrative prosecution. (art 109/5 AAO).

${ }^{14}$ Various possibilities see.

${ }^{15}$ Id.

${ }^{16}$ Formally this is an independent EM decision, but in practice this will mostly be done in consultation with the PPS.

${ }^{17}$ bulk reaction by investigative authority.

${ }^{18}$ Only in juvenile cases.

${ }^{19}$ Police may issue administrative order. See supra note 1 and 4.

${ }^{20}$ Falta-procedure done by the EM also sitting as the single judge without written indictment by the PPS but only an oral statement.

${ }^{21}$ PPS may ask the court to issue a penal order. See Table $2 b$.

${ }^{22}$ For juveniles only.

${ }^{23}$ PPS may issue an administrative order. See supra note 1, 4 and 6.

of criminal proceedings and summary proceedings are applicable only to less serious crimes, i.e. crimes punishable up to three, five or ten years of imprisonment.

Accelerated proceedings are used in proceedings before a municipal court for offences punishable by fine or imprisonment for a term of less than five years as a principal punishment. It is neither a matter of choice for the PPS whether or not to initiate accelerated proceedings in such cases, nor may the court disagree with the use of accelerated proceedings if the legal requirements for the proceedings are met. For years around $90 \%$ of all charged cases are conducted by accelerated proceedings.

Penal order proceedings provide a further type of procedural simplification. The PPS requests in a written motion to indict that the court issues a penal order imposing a certain punishment or measure upon the defendant without holding a trial. The penal order was introduced into Croatian criminal procedure in 1998 to decrease the workload of courts in less serious cases and since then we have witnessed an increase in its use. The PPS still does not use this opportunity frequently enough, however. In 2006 the PPS made an application for a penal order in 6.705 cases ( $26.5 \%$ of all charged cases). The vast majority of all PPS applications result in a penal order being issued - the State Attorney General estimates for 2006 that a penal order was granted in at least 5.000 cases ( $80 \%$ of applications).

The Code of Criminal Procedure (CCP) does not envisage the PPS as able to drop a case due to a lack of public interest.

The PPS can preliminarily forego bringing public charges for a less serious crime (an offence punishable by a fine or a sentence of imprisonment for a term of less than three years with of a lower degree of guilt, where the scope of the damaging consequences does 
not require the public benefit of criminal prosecution) subject to prior consent from the victim and provided that the suspect gives his or her consent that $\mathrm{s} /$ he is willing to fulfil one or more obligations (conditional disposal). This possibility is used extremely rarely. In 2006 in only 146 cases $(0.6 \%)$ did the PPS use a conditional disposal.

Rendering a judgment at the request of the parties to investigation is a new instrument, introduced in Croatian criminal procedure in 2002, which enables a case-ending settlement during the pre-trial stage. Before the termination of the investigation in criminal proceedings for criminal offences for which a sentence of imprisonment for a term of up to ten years may be pronounced, the suspect alone or parties jointly may submit a request to the examining magistrate to render a judgment for the defendant of no more than one third of the upper limit of the prescribed sentence. The party or parties should exactly state the type and the extent of the sentence that they request the examining magistrate to pronounce. The number of such judgments is still negligible.

In accelerated proceedings it is possible to achieve a negotiated case-ending settlement during trial. If the defendant pleads guilty to all counts of the charge the court, having interrogated the defendant and assessing his confession to be in compliance with the evidence examined so far, will examine only the evidence of relevance to the ruling on penal sanctions thereafter. Consequently a guilty plea shortens the proceedings. In that case, if the defendant gives his or her consent to the type and scope of the penal sanctions requested in the indictment, the court in its judgment may not pronounce any other type of penal sanctions or a more severe punishment than was proposed (see also Turković 2008).

Recent developments in England \& Wales ${ }^{6}$ show much contradiction in the strategic approach adopted towards which forms of behaviour should have some sanction applied to them. Broadly there are two approaches, showing some bipolarity:

a) As a result of increased penality among politicians and the public, the law has been changed to increase the types of behaviour that could have some form of sanction applied. Since 1999 this has developed to include behaviour not criminal but more accurately classified as un-neighbourly, uncivil or threatening. This behaviour has the generic title of Anti-Social Behaviour ${ }^{7}$ and a new aspect of civil law has been devised to cope with such activity. Police, local authorities, housing associations or other social groupings can apply to a civil court for an Anti-Social Behavioural Order (ASBO) to be issued against a person (occasionally a group such as a family) who can be shown to be causing distress, annoyance, or incivility to others. There are three important legal characteristics of such orders that appeal to both politicians and those members of the public who wish such behaviour curbed.

1. Although examples of such behaviour are given in the legislation, ASBOs can apply to a very wide range of behaviours and can be tailored to the particular situation. For example, research carried out to justify the introduction of ASBOs showed that incidents of anti-social behaviour were around four or five times the amount of crime typically recorded by the police.

\footnotetext{
${ }^{6}$ C. Lewis. Institute of Criminal Justice Studies, Portsmouth University House, Winston Churchill Avenue, Portsmouth, Hampshire PO1 2UP UK. e-mail: chris.lewis@port.ac.uk. See http://www.homeoffice.gov.uk/ anti-social-behaviour/.

${ }^{7}$ Anti-social behaviour (ASB) includes a variety of behaviour covering a whole complex of selfish and unacceptable activity that can blight the quality of community life: examples include, but are not confined to: nuisance neighbours, rowdy and nuisance behaviour, yobbish behaviour and intimidating groups taking over public spaces, vandalism, graffiti and fly-posting, people dealing and buying drugs on the street, people dumping rubbish and abandoning cars, begging and anti-social drinking and the misuse of fireworks.
} 
2. The burden of proof on the authorities is lower than the standard of proof in a criminal case. This reduces the evidential burden on those bringing the case to court.

3. If an ASBO can later be shown to have been breached, then the person against whom the order was made can become subject to the CJS and can be sentenced in court for breach of the order. Such a sentence could be a fine, probation order, community service, or even custody. However, custody has happened in only a small number of cases, in fact, only between 1,000-1,500 ASBOs have been issued each year, showing that despite the publicity granted for such new legislation, ASBOs are, in fact being used quite sparingly so far.

b) Of much more importance in terms of the numbers of people affected, is the form of 'procedural decriminalistion' used within the English criminal justice system. This has grown up slowly, over a period of many years. They mainly involve the police, as the prosecution service has no powers of sanction as such:

Police Cautions These are warnings given to offenders who admit their guilt, usually for minor offences but also for some more serious offences. Sometime these cautions are conditional upon the offender carrying out some form of action (eg. compensation, reparation, avoiding certain geographical areas, attending some form of treatment or educative process.) Such cautions have been given by the police, as a form of non-legal decriminalisation, for many years, but more recently the police are also agents of the prosecution service in giving such cautions. Although cautions as such have no sanction, records are kept and repeat offenders stand a very much higher chance of a court appearance.

Police Fixed Penalties for certain offences, the police, if the offender admits his guilt, can award a fixed financial penalty, usually under 100 pounds, and take no further action. Although such fixed penalties have been given for motoring offences of all sorts for many years, and can also involve the imposition of penalty points on a driving licence, more recently police powers have been extended to other public order offences as well as stealing small amounts from shops. The prosecutor has no say in such actions and some prosecutors are concerned about the lack of due process in the way such powers are sometimes carried out by the police.

Police Action Against Cannabis Use Since 2004, police have been given the power to award formal warnings for cannabis possession. This is mainly used to cope with cannabis use in public places. It imposes no sanctions as such, but does enable the police to keep a record and use the award of a formal warning in evidence if the offence is repeated.

Accelerated Court Proceedings Although not classified as such, cases that are not subject to a police fixed penalty, eg some forms of licence evasion, are often bundled together in court and 'nodded through' in large numbers by the court (e.g. the large numbers who do not pay their TV licence and are prosecuted and fined). The effect on them is the same as a fixed penalty fine with the court the agent rather than the police. The English system cannot either decriminalise the offence or allow an agency to impose an out-of court fixed penalty (see also Lewis 2006).

In France $^{8}$ the category of criminal offence covers a very wide range of illegal acts, ranking from the first class of contraventions (maximum penalty $38 €$ fine) to crimes punished by more

\footnotetext{
${ }_{8}^{8}$ B. Aubusson de Cavarlay. Center for Sociological Research on Law and Penal Institutions (CESDIP), Ministère de Justice/CNRS, 43 Boulevard Vauban, F-78280 Guyancourt (Paris), France. e-mail: aubusson@ext.jussieu.fr.
} 
than 10 years of imprisonment. The middle category of délits itself is also a wide one the maximum penalty starting at 6 months of imprisonment and reaching 10 years at the highest level. Within contraventions there are five classes according to the maximum fine incurred. For the fifth class (fine from 750 to 1500€), the tribunal de police is the competent jurisdiction as for other contraventions but cases are dealt with by the public prosecutor according to the same rule as for délits (and the same alternative disposals can be used).

A great number of contraventions of class 1 to 4 are not treated by the CJS itself; the ordinary "sanction" is the payment of a fine directly to the Treasury (fine stamp or electronic payment). This is a form of procedural decriminalisation but it should be noticed that these administrative decision can be contested and sometimes be prosecuted as ordinary criminal offences. Ordinary prosecution is the rule when a victim, in the capacity of a civil party, has applied for damages (petty violence without disability or aggravating circumstances) but the public prosecution service is a specific one and involves a police officer appointed by the local public prosecutor. Since 2002, new jurisdictions have been settled in order to increase the number of such minor offences going to court (jurisdictions de proximité and non professional stipendiary magistrates).

Criminal offences treated by the public prosecutor himself include crimes, délits and contraventions of the 5 th class. Convictions for these criminal offences are all recorded in the same way. Crimes and the most serious délits will involve the examining magistrate before going to court and such cases will go to court if the judicial inquiry leads to enough evidence against the suspect. For the remaining part of criminal offences reported to the public prosecutor all legal possibilities are actually used, from simple drop (expediency principle) to court proceedings with a great variety of alternative solutions in the middle. Penal orders appeared a long time ago for contraventions (including the fifth class) and some specific alternative proceedings where already available in the 1970's (medical care for drug users) but the significant increase of these disposals started during the 1980's and were formally included in the criminal law in 1993 and thereafter. During this period (mid 1980's and before 2002) the main goal was to reduce the proportion of cases dropped without any "penal response" and this proportion actually decreased whereas the number of cases going to court was stable. These disposals allowed the public prosecutor to decide some kind of sanctions without court agreement (conditional drop, mediation, transaction). Since 2002, new kinds of proceedings formally involving the courts have been introduced in order to increase the number of cases leading to a formal conviction and the enforcement of ordinary criminal sanction (including imprisonment). The use of penal orders has been extended to cover serious traffic offences (délits as drunk driving) and a kind of guilty plea as been introduced (comparution sur reconnaissance préalable de culpabilité); in both cases, the sanction is proposed by the prosecutor and accepted by the offender, before court agreement for the CRPC, after court agreement for penal orders. These two solutions represented about one quarter of convictions for délits and contraventions for the 5th class in 2006 whereas in 2002 the penal order (available only for contraventions) represented only one of ten convictions.

It should however also be noted that in France, during the same period, an important shift occurred among prosecuted cases according to offence types: thefts and property crimes are decreasing, violent crimes which are now considered as more important from the victims' point of view (robbery, assault, sexual offences) are increasing and traffic offences are becoming more serious legally (shift from contraventions to délits). The changes in the use of different disposals are not only the consequence of caseload management, they also reflect changes in penal policy; for instance mediation was considered as a convenient 
response to domestic violence ten years ago but court proceedings and severe sanctions are now firmly recommended by ministerial guidelines (see also Aubusson 2006).

Germany has seen a large number of offences removed from the CJS in and turned into "Ordnungswidrigkeiten", i.e. material decriminalisation in order to achieve relief for the CJS. This still proved to be inadequate, however, and prosecutorial discretion to drop and dispose of cases was introduced to the criminal procedure code, providing a legislative basis for what had become common practice.

Discretionary drops and disposals account for about $1 / 5$ th of cases dealt with by the CJS. These procedural options are subject to court approval except in minor cases. It is rare, however, that a court rejects a prosecution proposal and thus this control can be regarded as cursory. Beyond that, penal order and accelerated proceedings are available as further streamlining options. Conviction by penal order tends to be just as frequent as normal full proceedings, occuring in about $20 \%$ of cases, reflecting its importance and the degree of convenience associated with it whilst accelerated proceedings are barely used. The latter in fact present only mild forms of relief in comparison to full proceedings and are presumably rarely used because of this. Prosecution guided police drops as well as negotiated casesettlements (arranged with the defence by the court) are currently subject to discussion (see also Elsner and Peters 2006).

In the modern history of Hungarian ${ }^{9}$ criminal justice some forms of behaviour were decriminalised for different reasons. After the social changes in the 1990's some crimes became administrative offences (e.g. prostitution) or were deleted from the list of punishable acts.

The other large group to become the object of material decriminalisation consists of crimes against property and financial crimes. Most of these offences are punishable depending upon the value, damage, the amount of reduction in tax, etc. involved. Due to inflation the lower and upper limits of these crimes have changed regularly and in this way offences committed in respect of a smaller value were placed in the category of administrative offences.

Some trace of procedural decriminalisation can be found in our CJS. The law allows the prosecutor and the court to leave some offences - however punishable and proven - unpunished. In the course of investigation the prosecutor shall terminate the investigation and omit to indict a criminal offence having no significance for the purpose of liability, due to the commission of another criminal offence of greater gravity and being the subject of the indictment. In this case the victim has right to legal remedy. If the superior prosecutor has rejected the protest of the victim the later may bring the case to court as a substitute private accuser.

Even in an earlier stage of the investigation - after the questioning of the suspect - the prosecutor may dispense with further investigation into such a criminal offence.

During court proceedings, the court may terminate the procedure - and during the trial omit the examination of evidence - due to a criminal offence having no significance for the purpose of liability as opposed to the more serious criminal offence also contained in the indictment. This means that an adequate sanction can be imposed without taking the less serious offence into consideration.

A discretional drop before the court stage is possible only in the case mentioned above or - before 1 July 2006 - when the specific ground for the preclusion of punishability, a negligible degree of danger for society, is established.

\footnotetext{
${ }^{9}$ E. Roth. Department of Criminal Procedure and Correctional Law Institute of Criminal Sciences Faculty of Law, University of Miskolc, 3515 Miskolc-Egyetemváros, Hungary. e-mail: jogerika@uni-miskolc.hu.
} 
When the investigation is complete the public prosecutor is authorised to take the next step: he may prosecute before the competent court or may divert the case. The discretionary power held by the public prosecutor became wider in the last decade. The main reason behind this legislative decision was the overloading of courts and the intent to guarantee that cases can be closed within a reasonable time.

However, prosecution remains the rule due to the principle of legality, which is one of the basic principles of Hungarian criminal procedure. The prosecutor may dispose of cases with or without imposing a condition. The suspect's consent is necessary to close the procedure without a court decision.

Within 30 days of receiving the documents from the investigating authority the prosecutor shall examine the files of the case and may: terminate the investigation, file an indictment, make a decision on partial omission of the indictment postponement of an indictment, or finally send the case for mediation procedure.

If the prosecutor is convinced that filing an indictment is the most appropriate decision he has different options for bringing the offender before court because simplified and quick procedures are available in the Hungarian system. Omission of trial (penal order) and arraignment (bringing the accused before the court within 15 days of the commission of the offence) and the adjudication of the case in open session (waiver of the trial) are used in accordance with directions given by the Prosecutor General.

While the omission of trial is used very frequently (32.6\% of all indictments in 2005) and where the legal requirements are met arraignment is regarded as the best solution ( $8.9 \%$ of all indictments in 2005), the public prosecutor seems to be very reluctant to propose the waiver of trial procedure (used only in 410 cases $-0.5 \%$ - in 2005).

The suspect has a right to legal remedy against a conditional disposal if the public prosecutor postpones the filing of an indictment and the former is allowed to protest against the decision to terminate the investigation with a reprimand. When the suspect does not accept the decision of the public prosecutor, full criminal proceeding will be resumed. This entails a risk for the suspect because the court may impose punishment. Of course suspects exercise their rights to legal remedy only when they regard themselves as innocent.

Legal remedy is available not only against decisions of the prosecutor but also when the court deals with the case in accelerated, simplified proceedings. In the appeal instance a restriction preventing greater severity binds the court of second instance; it is prohibited to convict the accused or increase his punishment if the appeal was lodged only by him.

Where the trial is omitted (penal order proceedings) the first court decision is not subject to appeal but the parties may request that a trial be held. In this case the restriction against greater severity also binds.

In Hungary unlawful behaviour is traditionally divided into two groups. The first group constitutes criminal offences and is subject to criminal sanctions while offences of the other are dealt with by administrative authorities which are entitled to impose less serious noncriminal sanctions. So in Hungary criminal offences must be dealt with by the CJS. Very similar but less serious criminal-like breaches of the law are administrative offences. These forms of behaviour are dealt with by a procedure regulated by a separate act.

There are several authorities - among others the police — dealing with administrative offences. When the administrative offence is punishable by custody the local court shall act as a single judge and hold trial. Other administrative offences may be dealt by the court only when the offender exercising his right to remedy lodges an appeal against the decision of the administrative authority. 
Criminal offences consist of two groups: a felony is an act of crime perpetrated intentionally and punishable by more than two years of imprisonment. Any other act of crime is a misdemeanour. This classification has importance only in substantive criminal law because since 1 July of 2003 (when the new Code of Criminal Procedure entered into force) criminal procedure is unified, both felonies and misdemeanours are dealt with by the application of the same procedural rules in the CJS (see also Roth 2008).

The Netherlands ${ }^{10}$ Since about 1990 the vast majority (80-90\%) of all offences were decriminalised. These were all traffic offences except the more serious traffic offences like excessive speeding or drunk driving. Although legally still referred to as 'punishable acts', these offences are not part of the criminal code anymore and are handled administratively.

The remaining offences are divided into two categories: infractions and crimes. Although there are some differences between these categories in procedural law, these are not substantial. Both can end in a police decision to end the case (but these are more common for infractions and less used for crimes), a drop or disposal by the prosecutor or a court decision. Crimes can be divided into two categories, less serious and more serious crimes. This is not a division based on the law but is purely based on a practical decision by the prosecutor to bring the case before a single judge or a full bench of three judges.

The use of case-ending solutions alternative to a court decision has increased considerably during the last 20 years. A large proportion $(60 \%$ of infractions and $30 \%$ of crimes) of cases end with a conditional disposal (a transactie), either by the police or by the prosecution. In the coming years conditional disposals will be replaced gradually by a kind of penal order, the strafbeschikking. The difference to a conditional disposal is that the offender does not have to agree with the decision (but can appeal against the decision) and that it is considered to be a formal sanction and a guilty verdict.

Plea bargaining or guilty plea proceedings are not known in the Netherlands (see also Blom and Smit 2006).

It is not an easy task to indicate clearly what socially-not-accepted behaviour fall within the scope of the CJS in Poland. ${ }^{11}$ As was mentioned above the problem concerns mainly wykroczenia (petty offences). The border between them and "real" offences is not always obvious. For example: theft of a good of lesser value than about 50 Euro is a petty offence; if the value of the stolen good is higher it becomes an offence. The answer to the question: what are wykroczenie can be found in the Petty Offences Code (Kodeks wykroczeń) and in some other acts. However the answer what wykroczenie are in general is more complex. It is possible to construct the following definition: wykroczenie is a forbidden act of less social danger that an offence which is punishable according to criminal law.

The origin of the institution of petty offences (wykroczenia) is to be found in the late 60-ties of the 20th century. Mainly for timely political reasons (to show how the communist system causes the number of offences to decrease), the communist state decided to divide offences into two legal acts: Criminal Code and Petty Offences Code (Kodeks wykroczeń) and to prepare separate procedures for "classic" offences and for petty offences (wykroczenia). The first group

\footnotetext{
${ }^{10}$ P. Smit. Research and Documentation Center (WODC) of the Ministry of Justice, P.O. Box 2031, $2500 \mathrm{EH}$ The Hague, Netherlands. e-mail: p.r.smit@minjus.nl.

${ }^{11}$ P. Sobota. Office of the Commissioner for Civil Rights Protection, Al. Solidarności 77, PL-00-090 Warsaw, Poland. e-mail: p.sobota@brpo.gov.pl.
} 
remained under court's jurisdiction, whereas for the second a new administrative body was created (kolegia do spraw wykroczeń), where not judges (with the associated guaranties of independence) but clerks were dealing with cases. These bodies played a dishonourable role until the democratic changes in 1989. In these times it was rather obvious that wykroczenia are administrative offences dealt with by administrative body outside the CJS.

The situation changed when in the 1990s the CJS became engaged in proceedings concerning wykroczenia. Firstly a right to appeal to a regional court against decisions of the kolegium was introduced. Then cases concerning wykroczenia, when it was likely that a penalty of imprisonment would be imposed, were transferred to the criminal courts. Finally, after the Constitution of the Republic of Poland of 1997 came into force in 1998, it became clear, that under its provisions it is only the courts which can decide about guilt and punishment. In effect since 2001 proceedings concerning wykroczenia are dealt by with district courts (magistrate divisions), but the procedure is still different. Transmission of cases concerning wykroczenia to criminal courts together with the growing number of crimes (and growing number of other new court tasks) caused the Polish CJS to collapse at the beginning of 21 st century. This is not the place for deeper analysis, but it is sufficient to say that thousands of cases were not judged, falling foul to the statute of limitation.

The answer to the situation found were wide amendments in criminal procedure that came into force in July 2003. Since then a great number of cases are ended by way of negotiations. There are two forms of negotiated case ending: Prosecutors' Application for a Conviction without Trial and Voluntary Submission to Penalty. The latter way of case ending is becoming ever more popular: for example in 2006 about $40 \%$ of cases were ended in this way. There are of course still other alternative procedures aimed to fasten and shorten proceedings: conditional disposal and the penal order.

Characteristic of the Polish system is that only a court is entitled to end a case with a decision concerning guilt and punishment. This decision always takes the form of a verdict - in all categories of proceedings, i.e.: normal, negotiated, conditional disposal and penal order.

A new idea of speedy proceedings came into force in March 2007; the so-called "24 hour courts". The essence of the solution is that an offender caught red-handed is transmitted straight to a court, practically without a preparatory stage of proceedings. A court has to issue a verdict in a short time.

The only exception to the principle that it is exlusively a court that decides about guilt and punishment is the situation in which the police (and some other organs) end a case concerning a petty offence (wykroczenie) with a ticket fine. This may happen if an offender is caught red handed, or if there is no doubt about who was an offender. It is not obligatory for a perpetrator to accept the ticket - then a case is transmitted to court (magistrate division). If, however, he or she accepts a ticket it can be revoked only in exceptional circumstances by a court, i.e. when an offender's behaviour was not a petty offence at all. This solution is criticized, because sometimes it means that an obviously unfair police decision cannot be annulled, especially when an offender (after acceptance of a ticket) comes to the conclusion, that his or her guilt was not evident at all (see also Bulenda et al. 2006).

The general Western European movement towards the decriminalisation of some minor offences was followed with a particular trend in $\mathbf{S p a i n}^{12}$ because of its political situation during a good part of the twentieth century. Thus, the main changes to the criminal code took place during the final stages of the dictatorship and the first years of democracy (i.e. the 1970s

${ }_{12}$ M. Aebi and M. Balcells. Department of Criminology, University of Lausanne ICDP, Sorge, Batochime CH-1015 Lausanne, Switzerland. e-mail: Marcelo.Aebi@unil.ch. 
and the 1980s). During that period, many offences that were not compatible with a democratic regime, as well as some misdemeanours, were eliminated. With the introduction of a new criminal code, in 1995, a few offences were removed from CJS jurisdictions but, since then, the main tendency has been to introduce new offences. For example, the criminal code introduced additional socio-economic offences as well as offences against the environment. At the same time, harsher penalties were introduced, especially for domestic violence and terrorism. In that context, all minor forms of domestic violence, which were formerly considered misdemeanours, are currently considered to be crimes. Moreover, a reform introduced in 2003, states that when four misdemeanours of the same type are committed during the same year, the fourth offence should be considered as a crime instead of a misdemeanour. Somewhich ironically, the only offence that disappeared from the new criminal code was the refusal to join the army and the reason was that the army is no longer obligatory for male Spanish citizens.

In order to cope with the increased work burden placed upon the CJS due to this situation, Spain introduced modifications to criminal procedure. The main one was the creation of fast trials (juicios rápidos) in 2002. The goal was to accelerate the proceedings in cases where the investigative stage is regarded as simple and the offence is not a serious one. In that context, a soft form of plea bargaining was introduced via the so-called "agreed sentence" (juicio de conformidad). The results are mixed because, even if the fast trial and the agreed sentences are applied quite frequently, the CJS is still struggling.

In fact, the particularity of the Spanish situation stems from the fact that the legality principle is one of the pillars of the CJS. This states that the final decision about a criminal offence should always come from a court; thus, in principle, there is no possibility for the police or the PPS to drop or dispose cases (in that context, it seems that the country has two options to reduce the length of the criminal justice proceedings: to increase the number of courts or to replace the legality principle with the principle of opportunity) (see also Aebi and Balcells 2008).

The Swedish ${ }^{13}$ law doesn't know any categorisation of offences. All offences falling under criminal law legislation are "brott" (criminal offences), regardless of the seriousness of the act. Another category of offences, e.g. some kind of administrative offences, doesn't exist, at least formally (but see below). It means, for instance, that a murder is - formally — the same category of offence as a trivial traffic contravention. Under such circumstances it is clear that some "case filters" on the way to courts have to be present, in order to keep the caseload at a reasonable level. There are, in Sweden, three main methods of decreasing the caseload which have to be dealt with by courts.

The first way consists of a possibility of the Public Prosecution Service not to initiate prosecution in court (despite the valid principle of legality). The PPS may either decide to waive prosecution (which is, however, recorded in the suspect's criminal record), or decide simply "not to prosecute", if the PPS applies provisions of the substantive criminal law which provides for so called "special examination" whether some preconditions for indictment exist or not (there is a number of criminal offences that can be prosecuted in court only if there is a special public interest in prosecution).

The second way, which is particular to Sweden compared with other countries, is the possibility of the PPS to issue a penal order. The penal order has the same dignity as a court judgement and is recorded in the criminal register. But not only the PPS can issue a penal order. The police also has the power to issue a decision imposing a fine for a number of

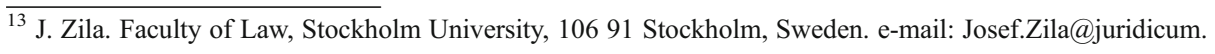
su.se. 
offences in road traffic and some other areas. Even this decision is considered as a final decision and is recorded in the criminal register.

The third solution was introduced into Swedish law in the seventies. A new type of sanction has been created, so called "sanction fees" (sanktionsavgift). It is a fine, but the sanction is imposed by administrative authorities. There are about twenty different sanctions of this kind to be found in the Swedish law, especially in relation to taxes. Infringements which can lead to this kind of sanction are not classified by any common term. Furthermore, in some situations, the sanction fees can be imposed for an act which also is criminalized. There is a certain number of sanction fees which can be imposed for acts which are not criminal offences. The regulation of this branch as a whole is unsystematic and rather confusing (see also Zila 2006).

In Switzerland, ${ }^{14}$ the 26 cantonal codes of criminal procedure provide, besides the normal proceedings with full trial, for a simplified procedure leading to a summary verdict and sentence, called penal order. It is routinely employed in cases involving minor offences. This system allows prosecutors or, in some cantons, examining magistrates, to issue a verdict and a sentence without any or, at least, without a full hearing. In nearly all cantons, roughly 9 procedures out of 10 that are not dropped during the investigation end with a summary decision of this kind. Despite many obvious parallels between penal orders and Americantype forms of plea bargaining, this procedure is possible only if no sentence beyond 6 months is envisaged by the prosecutor. A further difference is the fact that defendants can, within a deadline ranging from 10 to 30 days (depending upon the canton), insist on a full trial without any risk of worsening their prospects. This summary procedure should not be confused with the imposition of fines for minor traffic offences by the police. Police cautioning or any other informal disposals by the police are not available in Switzerland. Prosecutors, however, have limited powers to end prosecutions in trivial cases, or whenever the evidence available is not sufficient (see also Gilliéron and Killias 2008).

In Turkey, ${ }^{15}$ certain offences, which were regulated as infringements in the old penal code, were removed from the new penal code (of 2005) and placed into the Offences Against Order Act (Ordnungswidrigkeitengesetz). Many of these offences had become outdated, like entering public space in female attire or dancing in such. Many of these offences were in any case intended to be dealt with by accelerated proceedings or prepayment by the old penal code. The praxis now is that such cases are brought directly to the PPS and settled in this way.

The new criminal procedure code (of 2005) also provides for prosecutorial and court discretion to drop cases. The scope of the of discretion to drop was extended for cases involving juveniles and elderly suspects (see also Hakeri 2008).

\section{Concluding Comments}

Obviously a range of options such as described above provides flexibility within criminal justice system and possibilities without which the systems studied here would not be able to master their case-loads. The negative side of this is that the state effectively imposes a sanction

\footnotetext{
${ }^{14}$ C. Gilliéron and M. Killias. Chair for Criminology and Criminal Law, Rechtswissenschaftliches Institut, University of Zürich, Rämistrasse, 74/39, 8001 Zürich, Switzerland. e-mail: martin.killias@rwi.uzh.chw.

${ }^{15} \mathrm{H}$. Hakeri. Chair for criminal law, criminal procedure law and medical law, Law Faculty of Selcuk University, Hukuk Fakültesi, Ceza ve Ceza Usul Hukukuk, Anabilim Dalı Başkanı, Alaettin Keykubat Kampüsü Konya, Turkey. e-mail: hakeri@selcuk.edu.tr.
} 
of sorts upon its citizens - whether entirely outside the CJS or via corner-cutting proceedings within it - without the protection of full criminal proceedings intended to ensure against incorrect conviction and punishment. Thus the chances of incorrect treatment are raised. All of the systems studied allow for an appeal procedure to counter this. Exceptionally there is some risk for the suspect in raising objections; the appeal instance is likely to impose a higher penalty if it considers the person guilty. In other words, as the alternative penalty is only a sanction of sorts and no criminal record follows, there may be a higher chance that factually innocent suspects, comply with the procedure to avoid a higher risk or because they do not understand that they are in fact not liable for punishment. The risk of this infringement is, arguably, to be weighed against the practicalities of dealing with the offences as well as the benefits of decriminalisation to the "offenders". The counter argument is that human rights principles do not allow a pragmatic approach such as this; wherever the state claims a right to intervene with a citizen's rights by imposing a sanction, it is required to prove guilt.

A further issue is the question as to where the line between criminal and non-criminal offences should be drawn as well as which offences it is legitimate to deal with by drops, disposals and non-public convicting proceedings. Factors of political viability and convenience may and indeed are likely be relevant here. This may mean that lines are drawn controversially. The countryspecific details provided above leave little doubt that we are far from a European norm on this; whilst the British system for example includes begging and drinking in public as matters affecting social order, other states are far from this.

Furthermore, in as far as a line is drawn pragmatically, guided merely by the number of cases: meaning that more frequently committed offences will be decriminalised or subjected to milder consequences or less intrusive proceedings, in order to provide CJS relief, this may lead to a very strange situation indeed in as far as determining principles behind the criminal law are concerned. Equivalently culpable conduct (however this is determined) may face very different state reactions. ${ }^{16}$ This may in turn undermine the legitimacy of the respective CJS.

\section{References}

Aebi, M., \& Balcells, M. (2008). The prosecution service function within the Spanish criminal justice system. European Journal on Criminal Policy and Research, 14(2-3), 311-331.

Aubusson de Cavarlay, B. (2006). The prosecution service function within the French criminal justice system. In: Jehle/Wade Coping with overloaded criminal justice systems - The rise of prosecutorial power across Europe pp. 185-205. Berlin: Springer.

Blom, M., \& Smit, P. (2006). The prosecution service function within the Dutch criminal justice system. In: Jehle/Wade Coping with overloaded criminal justice systems - The rise of prosecutorial power across Europe pp. 237-256. Berlin: Springer.

Bulenda, T., Gruszczynska, B., Kremplewski, A., \& Sobota, P. (2006). The prosecution service function within the Polish criminal justice system. In J. M. Jehle, \& M. Wade (Eds.), Coping with overloaded criminal justice systems (pp. 257-284). Berlin: Springer.

Elsner, B., \& Peters, J. (2006). The prosecution service function within the German criminal justice system, In: Jehle/Wade Coping with overloaded criminal justice systems - The rise of prosecutorial power across Europe pp. 207-236. Berlin: Springer.

Elsner, B., Aebi, M., Aubusson de Cavarlay, B., Gilliéron, G., Hakeri, H., \& Jehle, J.-M., et al. (2008). The criminal justice approach: case examples. European Journal on Criminal Policy and Research, 14(2-3), $123-132$.

Gilliéron, G., \& Killias, M. (2008). The prosecution service function within the Swiss criminal justice system. European Journal on Criminal Policy and Research, 14(2-3), 333-352.

${ }^{16}$ Again for a more detailed examination of these issues see Wade (2006) p. 37 onwards, as well as Jehle et al. (2008). 
Hakeri, H. (2008). The prosecution service function within the Turkish criminal justice system. European Journal on Criminal Policy and Research, 14(2-3), 353-368.

Jehle, J. M., Smit, P., \& Zila, J. (2008). The public prosecutor as key-player: Prosecutorial case ending decisions. European Journal on Criminal Policy and Research, 14(2-3), 161-179.

Lewis, C. (2006). The prosecution service function within the English criminal justice system. In: Jehle/ Wade Coping with overloaded criminal justice systems - The rise of prosecutorial power across Europe pp. 151-184. Berlin: Springer.

Roth, E. (2008). The prosecution service function within the Hungarian criminal justice system. European Journal on Criminal Policy and Research, 14(2-3), 289-309.

Turković, K. (2008). The prosecution service function within the Croatian criminal justice system. European Journal on Criminal Policy and Research, 14(2-3), 263-287.

Wade, M. (2006). The power to decide - prosecutorial control, diversion and punishment in European criminal justice systems today. In Jehle, J.-M., \& Wade, M. (Eds.), Coping with overloaded criminal justice systems (pp. 27-126). Berlin: Springer.

Zila, J. (2006). The prosecution service function within the Swedish criminal justice system pp. $285-311$. Berlin: Springer. 